\title{
PENGENALAN KONSEP SAINS PADA PENDIDIKAN ANAK USIA DINI MENGGUNAKAN EXPERIMENTAL METHOD (STUDI KASUS PADA TK NEGERI PEMBINA SUMENEP)
}

\author{
Lutfiana Fazat Azizah, Habibi, Siti Mariyam, Anik Anekawati \\ Prodi Pendidikan IPA, Universitas Wiraraja Sumenep
}

\begin{abstract}
ABSTRAK
Pengabdian kepada masyarakat telah dilaksanakan di TK Negeri Pembina Sumenep dengan judul "Pengenalan Konsep Sains pada Pendidikan Anak Usia Dini menggunakan Experimental Method (Studi Kasus pada TK Negeri Pembina Sumenep). Hasil observasi dari kondisi sekolah menunjukkan bahwa TK ini strategis untuk pelaksanaan kegiatan Pengabdian kepada Masyarakat karena merupakan TK rujukan dari semua TK se Kabupaten Sumenep.. Hasil evaluasi dari 10 kegiatan pengenalan konsep sains sederhana pada PAUD menunjukkan bahwa 56,7\% siswa mengenal dengan baik nama alat peraga, 15,7\% siswa mengenal peristiwa sains sebelum kegiatan dimulai, 78,2\% siswa berani mencoba setiap kegiatan, 75,2\% dapat menemukan konsep sains sendiri, dan 62,4\% dapat mengkomunikasikan temuannya.
\end{abstract}

Kata Kunci: Experimental Method, konsep sains, pendidikan, anak usia dini

\section{PENDAHULUAN}

Pendidikan merupakan modal dasar untuk menyiapkan insan yang berkualitas. Menurut Undang-undang Sisdiknas, Pendidikan adalah usaha sadar dan terencana untuk mewujudkan suasana belajar dan proses pembelajaran agar peserta didik secara aktif mengembangkan potensi dirinya.

Dengan diberlakukannya UU No. 20 Tahun 2003 maka sistem pendidikan di Indonesia terdiri dari pendidikan anak usia dini, pendidikan dasar, pendidikan menengah, dan pendidikan tinggi yang keseluruhannya merupakan kesatuan yang sistemik. PAUD diselenggarakan sebelum jenjang pendidikan dasar. PAUD dapat diselenggarakan melalui jalur pendidikan formal, nonformal, dan/atau informal. PAUD pada jalur pendidikan formal berbentuk Taman Kanak-kanak (TK), Raudatul Athfal (RA), atau bentuk lain yang sederajat. PAUD pada jalur pendidikan nonformal berbentuk Kelompok Bermain (KB), Taman Penitipan Anak (TPA), atau bentuk lain yang sederajat. PAUD pada jalur pendidikan informal berbentuk pendidikan keluarga atau pendidikan yang diselenggarakan oleh lingkungan.

Anak bukanlah orang dewasa dalam ukuran kecil. Oleh sebab itu, anak harus diperlakukan sesuai dengan tahap-tahap perkembangannya. Hanya saja, dalam praktik pendidikan sehari-hari, tidak selalu demikian yang terjadi. Banyak contoh yang menunjukkan betapa para orang tua dan masyarakat pada umumnya memperlakukan anak tidak sesuai dengan tingkat perkembangannya. Di dalam keluarga orang tua sering memaksakan keinginannya sesuai kehendaknya, di sekolah guru sering memberikan tekanan (preasure) tidak sesuai dengan tahap perkembangan anak, di berbagai media cetak/elektronika tekanan ini lebih tidak terbatas lagi, bahkan cenderung ekstrim.

Mencermati perkembangan anak dan perlunya pembelajaran pada anak usia dini, tampaklah bahwa ada dua hal yang perlu diperhatikan pada pendidikan anak usia dini, yakni: 1) materi pendidikan, dan 2) metode pendidikan yang dipakai. Secara singkat dapat dikatakan bahwa materi maupun metodologi pendidikan yang dipakai dalam rangka pendidikan anak usia dini harus benar-benar memperhatikan tingkat perkembangan mereka. Memperhatikan tingkat perkembangan berarti pula mempertimbangkan tugas perkembangan mereka, karena setiap periode perkembangan juga mengemban tugas perkembangan tertentu.

Undang-Undang Sistem Pendidikan Nasional dalam pasal 1 menegaskan bahwa, 
pendidikan anak usia dini adalah suatu upaya pembinaan yang ditujukan kepada anak sejak lahir sampai dengan usia enam tahun yang dilakukan melalui pemberian rangsangan pendidikan untuk membantu pertumbuhan dan perkembangan jasmani dan rohani agar anak memiliki kesiapan dalam memasuki pendidikan lebih lanjut.

Mengingat pentingnya sains di semua jenjang pendidikan, maka sangat diperlukan pengenalan dasar-dasar sains sejak usia dini. Metode pembelajaran anak usia dini meliputi bercerita, bercakap, tanya jawab, eksperimen (percobaan), pemberian tugas, sosiodrama, bermain peran, karya wisata, proyek dan demonstrasi. Metode yang cocok untuk kegiatan ini adalah metode percobaan. Kelebihan metode percobaan (Experimental Method) yaitu metode pengajarannya mendorong dan memberi kesempatan anak melakukan percobaan sendiri sehingga anak dapat mengamati sesuatu secara konkret. Kegiatan ini dapat dilakukan mulai umur empat sampai 12 tahun. Dengan demikian Pengenalan Konsep Sains Pada Pendidikan Anak Usia Dini Menggunakan Experimental Method sangat dibutuhkan.

\section{METODE PENELITIAN}

Metode kegiatan yang dilakukan untuk tercapainya tujuan pengabdian kepada masyarakat ini adalah metode eksperimen, merupakan pembelajaran sains yang dilaksanakan dalam bentuk bermain dengan percobaan. Sasaran kegiatan adalah siswa kelompok B2 TK Negeri Pembina Sumenep yang berjumlah 30 siswa, terdiri atas 18 laki-laki dan 12 perempuan pada tahun pelajaran 2010/2011. Dalam hal ini penerapan dilaksanakan pada KBM aktif, sekitar jam 07.30-08.30 WIB pada tanggal 4 Oktober 2010 - 6 November 2010.

\section{HASIL DAN PEMBAHASAN}

Pada kegiatan 1, belajar tentang benda yang mencair, $80 \%$ anak didik mengenal dengan baik nama alat peraga, 23\% anak didik mengenal dengan baik peristiwa mencair, $77 \%$ anak berani mencoba mencairkan es batu, $67 \%$ anak dapat menemukan peristiwa mencair,dan $60 \%$ anak dapat mengkomunikasikan temuannya.

Pada kegiatan 2, belajar tentang benda yang membeku, $70 \%$ anak didik mengenal dengan baik nama alat peraga, 23\% anak didik mengenal peristiwa membeku, $90 \%$ anak berani mencoba membekukan benda, $80 \%$ anak dapat menemukan peristiwa pembekuan,dan $67 \%$ anak dapat mengkomunikasikan temuannya.

Pada kegiatan 3, belajar tentang warna, $20 \%$ anak didik mengenal dengan baik nama alat peraga, $70 \%$ anak didik tidak mengenal peristiwa pencampuran warna sebelum kegiatan dimulai, $80 \%$ anak berani mencoba mencampurkan warna, $70 \%$ anak dapat menemukan peristiwa perubahan warna akibat pencampuran, dan $67 \%$ anak dapat mengkomunikasikan temuannya.

Pada kegiatan 4, belajar tentang pertumbuhan tanaman, $67 \%$ anak didik cukup mengenal nama alat peraga, 60\% anak didik tidak mengenal peristiwa pertumbuhan tanaman, 67\% anak berani mencoba menanam biji, 57\% anak dapat menemukan peristiwa tumbuhnya tanaman, dan 53\% anak dapat mengkomunikasikan temuannya.

Pada kegiatan 5, belajar tentang sifat udara, 67\% anak didik mengenal dengan baik nama alat peraga, $60 \%$ anak didik tidak mengenal peristiwa udara menempati ruang, $67 \%$ anak berani mencoba memasukkan udara dalam balon, $87 \%$ anak dapat menemukan peristiwa udara menempati ruang, dan $67 \%$ anak dapat mengkomunikasikan temuannya.

Pada kegiatan 6, belajar tentang sifat benda dalam air, $80 \%$ anak didik mengenal dengan baik nama alat peraga, $70 \%$ anak didik tidak mengenal peristiwa terapung, melayang, tenggelam, $80 \%$ anak berani mencoba memasukkan telor dalam gelas yang berisi air seperti yang dicontohkan gurunya, $70 \%$ anak dapat menemukan peristiwa terapung, melayang, tenggelam, dan $50 \%$ anak dapat mengkomunikasikan temuannya. 
Pada kegiatan 7 , belajar tentang sifat benda bila dijatuhkan, $80 \%$ anak didik mengenal dengan baik nama alat peraga, $60 \%$ anak didik tidak mengenal peristiwa gravitasi, $80 \%$ anak berani mencoba menjatuhkan dua benda yang berbeda berat, $77 \%$ anak dapat menemukan peristiwa gravitasi, dan $77 \%$ anak dapat mengkomunikasikan temuannya.

Pada kegiatan 8, belajar tentang sifat magnet, $70 \%$ anak didik mengenal dengan baik nama alat peraga, $73 \%$ kurang mengenal peristiwa gaya tarik magnet, $23 \%$ anak didik berani mencoba mendekatkan magnet pada benda-benda yang berbeda , $80 \%$ anak dapat menemukan peristiwa gaya tarik magnet terhadap benda-benda berbeda, $67 \%$ anak dapat mengkomunikasikan temuannya.

Pada kegiatan 9, melihat benda kecil dengan lup, 60\% anak didik mengenal dengan baik nama alat peraga, $67 \%$ mengenal dengan baik peristiwa perbesaran benda sebelum kegiatan dimulai, $67 \%$ anak didik berani mencoba menggunakan lup , $67 \%$ anak dapat menemukan sifat-sifat benda yang diamati dengan lup, 33\% anak dapat mengkomunikasikan temuannya.

Pada kegiatan 10, belajar tentang membedakan rasa, $40 \%$ anak didik mengenal dengan baik nama alat peraga, $83 \%$ anak dapat mengenal dengan baik perbedaan rasa sebelum kegiatan dimulai, 97\% anak didik berani mencoba merasakan macam-macam rasa, $97 \%$ anak dapat menemukan berbagai variasi rasa, $83 \%$ anak dapat mengkomunikasikan temuannya.

Rata-rata persentase dari seluruh kegiatan dapat dilihat pada tabel 1, menunjukkan bahwa dari berbagai macam kemampuan yang diajarkan, kemampuan yang mendominasi adalah keberanian anak mencoba setiap kegiatan sebesar 78,2\% dan kemampuan menemukan konsep sains sendiri sebesar $75,2 \%$.
Menurut Gunarti (2008), anak memiliki sifat ingin tahu yang tinggi. Sifat ingin tahu ini sesuai perkembangan intelektual anak pada masa usia dini ini sedang berkembang sangat cepat. Simpulsimpul syaraf di otaknya sibuk membangun konstruksi pengetahuan dengan cara mengasimilasi dan mengakomodasi rangsang-rangsang yang didapatnya melalui pengamatan dari lingkungan di sekitarnya. Salah satu cara untuk memuaskan keingintahuannya adalah dengan melakukan eksplorasi dan percobaan (trial and error). Oleh karena itu, metode eksperimen sangat mendukung optimalisasi potensi intelektual yang sesuai dengan taraf berpikir anak pada masa ini. Mengenai hal ini, Jean Piaget membuat pernyataan tentang bagaimana anak belajar, yaitu sebagai berikut.

"Anak seharusnya mampu melakukan percobaan dan penelitian sendiri. Pendidik, tentu saja, bisa menuntun anak-anak dengan menyediakan bahan-bahan yang tepat, tetapi yang terpenting agar anak dapat memahami sesuatu, ia harus membangun pengertian itu sendiri, ia harus menemukannya sendiri".

Melalui Experimental Method, proses yang ditekankan oleh Piaget di atas (anak harus melakukannya sendiri) dapat terlaksana. Mengapa anak harus mengalami sendiri dan tidak hanya melihat? Dalam kegiatan yang dilakukan sendiri, anak menggunakan kelima panca inderanya dan mengaktifkan otaknya yang didukung oleh perbuatan-perbuatan dari seluruh fungsi anggota tubuhnya, seperti memegang, merasakan, membaui, mengamati, mendengar, mengecap. Dalam kegiatan eksperimen ini terjadi proses berpikir logis, analisis, kritis dan sintesis yang membangun suatu pengetahuan baru. Tentu saja kesemua itu saling menguatkan untuk menanamkan kesan yang mendalam didalam diri anak mengenai sesuatu yang sedang diselidiki tersebut.

Tabel 1. Rata-Rata Persentase Dari Seluruh Kegiatan

\begin{tabular}{|c|c|c|c|c|c|c|c|c|c|c|c|c|c|c|}
\hline \multicolumn{3}{|c|}{ E1 } & \multicolumn{3}{|c|}{ E2 } & \multicolumn{3}{c|}{ E3 } & \multicolumn{3}{c|}{ E4 } & \multicolumn{3}{c|}{ E5 } \\
\hline B & $C$ & K & B & C & K & B & C & K & B & C & K & B & C & K \\
\hline 56.7 & 34.7 & 8.6 & 15.7 & 28.3 & 56 & 78.2 & 21.8 & 0 & 75.2 & 24.8 & 0 & 62.4 & 28.9 & 8.7 \\
\hline
\end{tabular}


Pada tabel di atas, pada kolom E2, dapat dilihat bahwa hanya $15,7 \%$ anak yang dapat mengenal dengan baik konsep sains sebelum kegiatan dimulai, 28,3\% anak cukup mengenal konsep sains dan 56\% anak kurang mengenal konsep sains.

Salah satu contoh, saat melakukan kegiatan 1, anak tahu jika es batu dibiarkan di udara terbuka akan berubah menjadi air. Tapi kebanyakan mereka jika ditanya "disebut peristiwa apakah itu?", sebagian besar mereka tidak dapat menjawab. Padahal biasanya anak-anak kalau ditanya tentang sesuatu yang sudah dikenalnya, anak sudah bisa menjawab dengan kata-kata pula. Mengapa sebagian besar mereka tidak dapat menjawab ? Hal ini menunjukkan bahwa mereka belum mengenal istilah/ kosakata "mencair".

Sesuai dengan hukum

perkembangan, yaitu hukum konvergensi yang dikemukakan oleh William Stern (Gunarti, 2008), pertumbuhan dan perkembangan yang dialami seorang anak manusia dipengaruhi oleh faktor lingkungan dan pembawaan. Sehingga dapat diketahui bahwa sebanyak $15,7 \%$ anak yang dapat mengenal dengan baik konsep sains sebelum kegiatan dimulai adalah anak yang mendapat stimulasi atau rangsangan pendidikan dengan baik dari lingkungannya. 28,3\% anak yang cukup mengenal konsep sains adalah anak-anak yang cukup mendapat stimulasi atau rangsangan pendidikan dari lingkungannya, dan $56 \%$ anak yang kurang mengenal konsep sains adalah anak-anak yang kurang mendapat stimulasi atau rangsangan pendidikan dari lingkungannya.

\section{KESIMPULAN DAN SARAN 4.1 Kesimpulan}

Berdasarkan hasil belajar siswa serta pembahasan sebelumnya maka dapat disimpulkan 2 hal, yaitu: 1) Mengenalkan konsep sains pada PAUD menggunakan Experimental Method dengan mengenalkan alat peraga dan peristiwa terhadap siswa dengan cara mengamati proses dan hasil percobaan pada setiap kegiatan sehingga anak menemukan jawaban dengan usaha sendiri berdasarkan fakta yang benar. 2) Dari 10 kegiatan yang telah dilakukan dapat disimpulkan bahwa 56,7\% siswa mengenal dengan baik nama alat peraga, $15,7 \%$ siswa mengenal peristiwa sains sebelum kegiatan dimulai, 78,2\% siswa berani mencoba setiap kegiatan, 75,2\% dapat menemukan konsep sains sendiri, dan $62,4 \%$ dapat mengkomunikasikan temuannya.

\subsection{Saran}

Perlu adanya penelitian lebih lanjut bagaimana meningkatkan kemampuan siswa memahami konsep-konsep sains sederhana dan memecahkan masalah sederhana dalam kehidupan sehari-hari.

\section{DAFTAR PUSTAKA}

Anonim. (2004). Kurikulum 2004 Standar Kompetensi TK dan RA. Jakarta. Depdiknas.

Asmawati, Luluk, dkk. (2008). Pengelolaan Kegiatan Pengembangan Anak Usia Dini. Edisi 1. Jakarta. Universitas Terbuka.

Gunarti, Winda, dkk. (2008). Metode Pengembangan Perilaku dan Kemampuan Dasar Anak Usia Dini. Edisi 1. Jakarta. Universitas Terbuka.

Megawangi, Ratna, dkk. (2008). Mari Kita Akhiri Kekerasan Pada Anak. Penerbit Indonesia Heritage Foundation.

Nugraha, Ali, dkk. (2008). Dasar-Dasar Matematika dan Sains. Cetakan 6. Jakarta. Universitas Terbuka.

Nugraha, Ali, dkk. (2009). Program Pelibatan Orang Tua dan Masyarakat. Edisi 1. Jakarta. Universitas Terbuka.

Wijana, W.D., dkk. (2008). Kurikulum Pendidikan Anak Usia Dini. Edisi 1. Jakarta. Universitas Terbuka.

Yufiarti, dkk. (2008). Profesionalitas Guru PAUD. Edisi 1. Jakarta. Universitas Terbuka.

http://forumpaudkabupatenbekasi.blog.dada .net/post/1207082433/KERANGKADASAR-KURIKULUM- 
PENDIDIKAN-ANAK-USIA-DINI. diakses tanggal 23 Agustus 2010.

http://www.jugaguru.com/column/21/tahun/ 2008/bulan/12/tanggal/19/id/849.

diakses tanggal 25 Agustus 2010. 